\title{
FAMILIAL HYPERAMYLASEMIA
}

\author{
Yu Kar Ling Koda and Eliana Vidolin
}

KODA YKL et al. - Familial hyperamylasemia. Rev. Hosp. Clín. Fac. Med. S. Paulo 57(2):77-82, 2002.

A 7-year-old white boy was referred to us with a history of 3 attacks of hypogastric pain over the previous 2 years and persistently elevated serum amylase concentrations. At physical examination, he was well with no evidence of clinical abnormalities. His weight and height were normal. Laboratory diagnostic investigations were all normal except for the presence of Ascaris lumbricoides in the feces and persistently elevated serum amylase levels. Serum amylase determinations in the family members were normal in his father and maternal grandmother but elevated in his mother, sister, maternal aunt, and uncle, all of whom asymptomatic. Macroamylasemia was excluded in the child and in the mother. The finding of persistently elevated amylasemia in the child and in the other family members spanning 3 generations, and the exclusion of diseases that lead to hyperamilasemia are consistent with the diagnosis of familial hyperamylasemia. Until now, only 1 similar case has been reported. Familial hyperamylasemia must be considered in the differential diagnosis of hyperamylasemias in childhood.

DESCRIPTORS: Hyperamylasemia. Amylase. Isoamylases. Macroamylase. Pancreatitis.

There is usually a tendency to suspect pancreatic disease whenever hyperamylasemia is encountered. However, there are a number of other conditions where elevation of total serum amylase may be a finding. These conditions include a long list such as cerebrovascular diseases, respiratory diseases, heart diseases, liver diseases, acute hypoxemia, cholelithiasis, diabetes mellitus, peptic ulcer, malignant tumor, renal failure, intra and extraabdominal surgeries, trauma, bulimia, anorexia nervosa, dyslipidemia, macroamylasemia, ethnic hyperamylasemia, chronic nonpathologic hyperamylasemia of pancreatic origin, and familial hyperamylasemia ${ }^{1-8}$.

The pancreas and salivary glands are the two organs that account for almost all of the serum amylase activity in normal persons. Hyperamylasemia can result either from an increased rate of entry of amylase into the circulation and/or from a decreased metabolic clearance of this enzyme ${ }^{9}$.

Clink et al. ${ }^{10}$ described 4 patterns of hyperamylasemia: 1) pancreatic hyperamylasemia, 2) salivary hyperamylasemia, 3) both salivary and pancreatic hyperamylasemia, and 4) macroamylasemia.

Pancreatic hyperamylasemia usually results from an insult to the pancreas or a loss of bowel integrity (infarction or perforation) that enhances absorption of amylase from the intestinal lumen ${ }^{9}$.

Salivary hyperamylasemia is observed in conditions that involve the salivary glands. However, other conditions such as chronic alcoholism, postoperative states (particularly postco-

From the Division of Gastroenterology of the Department of Pediatrics, Hospital das Clínicas, Faculty of Medicine, University of São Paulo. ronary bypass), lactic acidosis, diabetic ketosis, anorexia nervosa or bulimia, and malignant neoplasms may also cause salivary hyperamylasemia ${ }^{9,11}$.

Hyperamylasemia can also occur without pancreatic and/or salivary involvement from decreased metabolic clearance of amylase caused by renal failure or from macroamylasemia ${ }^{9}$. Total serum amylase alone is not enough to distinguish these various conditions. The measurement of salivary or pancreatic type isoamylase profiles in hyperamylasemic sera enhances the diagnostic accuracy ${ }^{9-14}$.

Macroamylasemia is an isolated biochemical abnormality caused by aggregation of serum amylase activity with immunoglobulins producing a high molecular weight amylase-protein complex in the serum. It is described as a frequent but benign cause of hyperamylasemia that requires no treatment and has been found to occur 
in a variety of diseases including various autoimmune disorders. It can be diagnosed by the presence of macroamylase in the serum and by low urine amylase concentrations in the presence of normal renal function ${ }^{7,15}$.

Tsianos et al. ${ }^{5}$ measured total serum amylase and the pancreatic and salivary isoamylase activities in 92 individuals without pancreatic or salivary disease, divided into 3 ethnic subgroups resident in the UK, namely native Britons, Asians, and West Indians. These authors found that immigrants had higher total serum amylase activities than the usually accepted reference range for Britons. They concluded that these differences in serum amylase may be genetically determined and called this condition ethnic hyperamylasemia.

In 1996, Gullo ${ }^{2}$ reported on persistent pancreatic hyperamylasemia in 18 young adult patients (10 men and 8 women; mean age 46.7 years; range 25 66 years) who had no evidence of pancreatic disease or history of alcohol abuse or drug intake. They were followed for a mean of 7.6 years. No pancreatic diseases appeared during the follow up, and serum amylase level remained abnormally high with a concomitant elevation of other pancreatic enzymes (trypsin and lipase). During follow up, enzyme concentrations remained elevated, although wide fluctuations and occasional transient normalization were observed. The author concluded that hyperamylasemia was a benign entity and called it chronic nonpathological hyperamylasemia of pancreatic origin..

In 1997, Cuckow et al. ${ }^{1}$ reported a case of a 6-year-old boy who underwent extensive investigation for recurrent abdominal pain and was found to have persistently raised serum amylase. Endoscopic retrograde cholangiopancreatography was normal, and macroamylasemia was excluded. Clearance studies suggested no evidence of a renal tubular defect, and serum lipase concentrations were normal.
Serum amylase concentrations were found to be raised in other family members spanning 3 generations, all of whom were asymptomatic, and the pattern of inheritance was consistent with an autosomal dominant condition. Both serum pancreatic and salivary isoamylases were raised in the child and the mother. These authors called this condition familial hyperamylasemia.

In this paper, we report a very similar case that, as far as we know, is the second description of this condition. Though familial hyperamylasemia is likely to be rare, it must be added to the long list of conditions that can include raised serum amylase levels and should be considered in the differential diagnosis of hyperamylasemia.

\section{CASE REPORT}

A 7-year-old white boy with a previous history of having presented, over the previous 2 years, 3 episodes of abdominal pain and persistently elevated total serum amylase was referred to our hospital for further investigation. The pain was at the hypogastrium, with each episode lasting about 30 minutes and resolving after treatment with antispasmodics. Each of these 3 episodes of abdominal pain was accompanied by vomiting and diarrhea. Between episodes he was well. At the last episode of abdominal pain he was admitted to the referring hospital at Manaus, capital of a state in northern Brazil, and his total serum amylase was found to be elevated: $236 \mathrm{U} / \mathrm{dL}$ (normal range 60-160U/dL). Subsequently, 3 more measurements of total serum amylase were made on different occasions when the child was asymptomatic, and the results were $298 \mathrm{U} / \mathrm{dL}$ (normal range 60-160 U/dL), $296 \mathrm{U} / \mathrm{dL}$ (normal range 60-160 U/dL), and 79 $\mathrm{U} / \mathrm{L}$ (normal range $\leq 40 \mathrm{U} / \mathrm{L}$ ) (Table1).

The child was the product of a fullterm pregnancy and was born by cesarean delivery. His birth weight was $3.65 \mathrm{~kg}$ and height was $51 \mathrm{~cm}$. There was no reference of consanguinity. As an infant, he had had no relevant diseases and also had no history of trauma or repeated or prolonged drug use.

On admission, he was well, without any complaint or abnormality at physical examination. His growth was normal (weight $=25.3 \mathrm{~kg}$; height $=123$ $\mathrm{cm})$. The abdomen was soft, non-tender, non-distended, and had no hepatosplenomegaly or mass.

Laboratory investigations performed at our hospital were all normal except for the presence of Ascaris lumbricoides in the fecal analysis and raised total serum amylase $139 \mathrm{U} / \mathrm{L}$ (normal range $\leq$ $120 \mathrm{U} / \mathrm{L})$. Two more samples of sera, taken at different occasions and not during the child's abdominal pain episodes, were sent to 2 different laboratories for the determination of total serum amylase. The result of the sample sent to a private laboratory in São Paulo (Laboratório Fleury) was 320 U/L (normal range $\leq 220 \mathrm{U} / \mathrm{L}$ ) and the other, sent to Mayo Medical Laboratories (Rochester, MN, USA), was $135 \mathrm{U} / \mathrm{L}$ (normal range 35-115 U/L) (Table 1).

The normal ranges of serum amylase in the different laboratories mentioned above were based on reference values provided by the companies producing the kits and were validated in a large series of healthy subjects.

Routine hematology, glycemia, protein electrophoresis, lipid profile, serum lipase concentrations, liver function tests, and fecal fat content were all normal. Clearance studies suggested no evidence of renal disease. LE cells and antinuclear antibody were negative. Urinary amylase and the ratio of amylase clearance to creatinine clearance were normal. The serum macroamylase determination performed at Mayo Clinical Laboratories (Rochester, MN, USA) was negative (Table 1).

The plain abdominal radiograph and abdominal ultrasound scan were 
Table 1 - Laboratory investigations.

\begin{tabular}{|c|c|}
\hline Serum amylase & $\begin{array}{l}236 \mathrm{U} / \mathrm{dL}(60-160 \mathrm{U} / \mathrm{dL})^{*} \\
298 \mathrm{U} / \mathrm{dL}(60-160 \mathrm{U} / \mathrm{dL})^{*} \\
296 \mathrm{U} / \mathrm{dL}(60-160 \mathrm{U} / \mathrm{dL})^{*} \\
79 \mathrm{U} / \mathrm{L}(\leq 40 \mathrm{U} / \mathrm{L})^{*} \\
139 \mathrm{U} / \mathrm{L}(\leq 120 \mathrm{U} / \mathrm{L})^{* *} \\
320 \mathrm{U} / \mathrm{L}(\leq 220 \mathrm{U} / \mathrm{L})^{* * *} \\
135 \mathrm{U} / \mathrm{L}(35-115 \mathrm{U} / \mathrm{L}) * * * *\end{array}$ \\
\hline Macroamylase & non detectable $* * * *$ \\
\hline $\mathrm{Hb}$ & $14.1 \mathrm{~g} / \mathrm{L}$ \\
\hline $\mathrm{Ht}$ & $42 \%$ \\
\hline White blood cell counts & 6 000/mm $3 \mathrm{~mm}^{3}(2 \% ; 38 \% ; 12 \% ; 1 \% ; 41 \% ; 6 \%)$ \\
\hline Platelets & $260000 / \mathrm{mm}^{2}$ \\
\hline ERS & $22 \mathrm{~mm} / \mathrm{h}$ \\
\hline Fecal parasites & Ascaris lumbricoides \\
\hline Urine analysis & normal \\
\hline Serum iron & $47 \mu \mathrm{g} / \mathrm{dL}(40-140 \mu \mathrm{g} / \mathrm{dL})$ \\
\hline Serum iron binding capacity & $330 \mathrm{mg} / \mathrm{dL}(240-508 \mathrm{mg} / \mathrm{dL})$ \\
\hline Serum lipase & $12 \mathrm{U} / \mathrm{L} ; 12 \mathrm{U} / \mathrm{L}$ and $15.8 \mathrm{U} / \mathrm{L}(2-18 \mathrm{U} / \mathrm{L})$ \\
\hline Glycemia & $83 \mathrm{mg} \% ; 88 \mathrm{mg} \%(80-120 \mathrm{mg} \%)$ \\
\hline Serum urea & $34 \mathrm{mg} \%(10-45 \mathrm{mg} \%)$ \\
\hline Serum creatinine & $0.6 \mathrm{mg} \%(0.4-0.8 \mathrm{mg} \%)$ \\
\hline Total protein & $6.9 \mathrm{~g} / \mathrm{dL}(6-8 \mathrm{~g} / \mathrm{dL})$ \\
\hline Albumin & $4.8 \mathrm{~g} / \mathrm{dL}(3.5-5.5 \mathrm{~g} / \mathrm{dL})$ \\
\hline$\alpha 1$ globulin & $0.3 \mathrm{~g} / \mathrm{dL}(0.2-0.4 \mathrm{~g} / \mathrm{dL})$ \\
\hline$\alpha 2$ globulin & $0.4 \mathrm{~g} / \mathrm{dL}(0.4-0.7 \mathrm{~g} / \mathrm{dL})$ \\
\hline$\beta$ globulin & $0.6 \mathrm{~g} / \mathrm{dL}(0.6-1.2 \mathrm{~g} / \mathrm{dL})$ \\
\hline$\gamma$ globulin & $0.8 \mathrm{~g} / \mathrm{dL}(0.7-1.6 \mathrm{~g} / \mathrm{dL})$ \\
\hline Total lipids & $480 \mathrm{mg} \%(400-1000 \mathrm{mg} \%)$ \\
\hline Triglycerides & $154 \mathrm{mg} \%(10-160 \mathrm{mg} \%)$ \\
\hline Cholesterol & $111 \mathrm{mg} \%(<240 \mathrm{mg} \%)$ \\
\hline HDL cholesterol & $32 \mathrm{mg} \%(30-65 \mathrm{mg} \%)$ \\
\hline LDL cholesterol & $42 \mathrm{mg} \%(<140 \mathrm{mg} \%)$ \\
\hline Cholesterol/ HDL & $3.4(<4.9)$ \\
\hline Urinary amylase & 1088 IU/L (170-2000 IU/L) \\
\hline Urinary creatinine & $0.84 \mathrm{~g} / \mathrm{L}$ \\
\hline Amylase clearance/creatinine clearance & $2.3 \%(1.2-3.8 \%)$ \\
\hline Fecal fat content & absent \\
\hline AST & $10 \mathrm{U} / \mathrm{L}(<20 \mathrm{U} / \mathrm{L})$ \\
\hline ALT & $12 \mathrm{U} / \mathrm{L}(<20 \mathrm{U} / \mathrm{L})$ \\
\hline$\gamma \mathrm{GT}$ & $6.2 \mathrm{IU} / \mathrm{L}(6-26 \mathrm{IU} / \mathrm{L})$ \\
\hline Alkaline phosphatase & $133 \mathrm{IU} / \mathrm{ml}(7-115 \mathrm{IU} / \mathrm{mL})$ \\
\hline Antinuclear antibody & negative \\
\hline LE cells & negative \\
\hline Upper digestive endoscopy & normal \\
\hline Plain abdominal radiograph & normal \\
\hline Abdominal ultrasound scan & no abnormality \\
\hline Cholangiopancreatography & normal \\
\hline
\end{tabular}

* results from the referring Hospital at Manaus (Caraway modified method)

** results from our hospital (enzymatic method)

*** results from a private laboratory in São Paulo (Laboratório Fleury - enzymatic method)

**** results from Mayo Medical Laboratories (Rochester, MN,USA)

normal range in parentheses.

normal. Endoscopic retrograde cholangiopancreatography showed normal ductal anatomy with a normal pancreatobiliary junction.

\section{Family members}

Blood was taken from the patient's father, mother, sister, maternal grand-
U/L- Laboratório Fleury) and 83 IU (normal range 10-125 IU - laboratory from the referring hospital at Manaus). The mother had raised total serum amylase on 2 occasions: $305 \mathrm{U} / \mathrm{L}$ (normal range $\leq 220 \mathrm{U} / \mathrm{L}$ - Laboratório Fleury) and 155 U/L (normal range 35115 U/L - Mayo Medical Laboratories). The sister, maternal uncle, and aunt also had raised concentrations of total serum amylase, which were respectively $164 \mathrm{U} / \mathrm{dL}$ (normal range 60$160 \mathrm{U} / \mathrm{dL}$ ), $188 \mathrm{U} / \mathrm{dL}$ (normal range 60-160 U/dL), and $211 \mathrm{U} / \mathrm{dL}$ (normal range 60-160 U/dL) (Fig.1). These determinations were all done at the referring hospital in Manaus. Serum macroamylase, measured at Mayo Medical Laboratories (Rochester, MN, USA), was also negative in the mother.

\section{DISCUSSION}

In our patient, the repeated findings of raised serum amylase levels led to exhaustive diagnostic investigation. However, we could not find evidence of any obvious pancreatic or salivary gland disease or of any of the reported conditions associated with raised serum amylase levels. Diabetes mellitus, dyslipidemia, renal disfunction, cholelithiasis, and liver disease were all excluded. Only intestinal Ascaris lumbricoides infection was detected.

Chronic nonpathological hyperamylasemia of pancreatic origin ${ }^{2}$, originally described in young adults (mean age 46.7 years; range 25-66 years) and characterized by elevated serum pancreatic amylase, is an unlikely diagnosis for our patient because in this condition, all pancreatic enzyme levels (amylase, lipase, and trypsin) remain elevated. Though we could not determine trypsin and isoamylase levels, which would have enhanced diagnostic accuracy, our patient was a 7years-old boy, and his serum lipase measurements made on 3 different oc- 


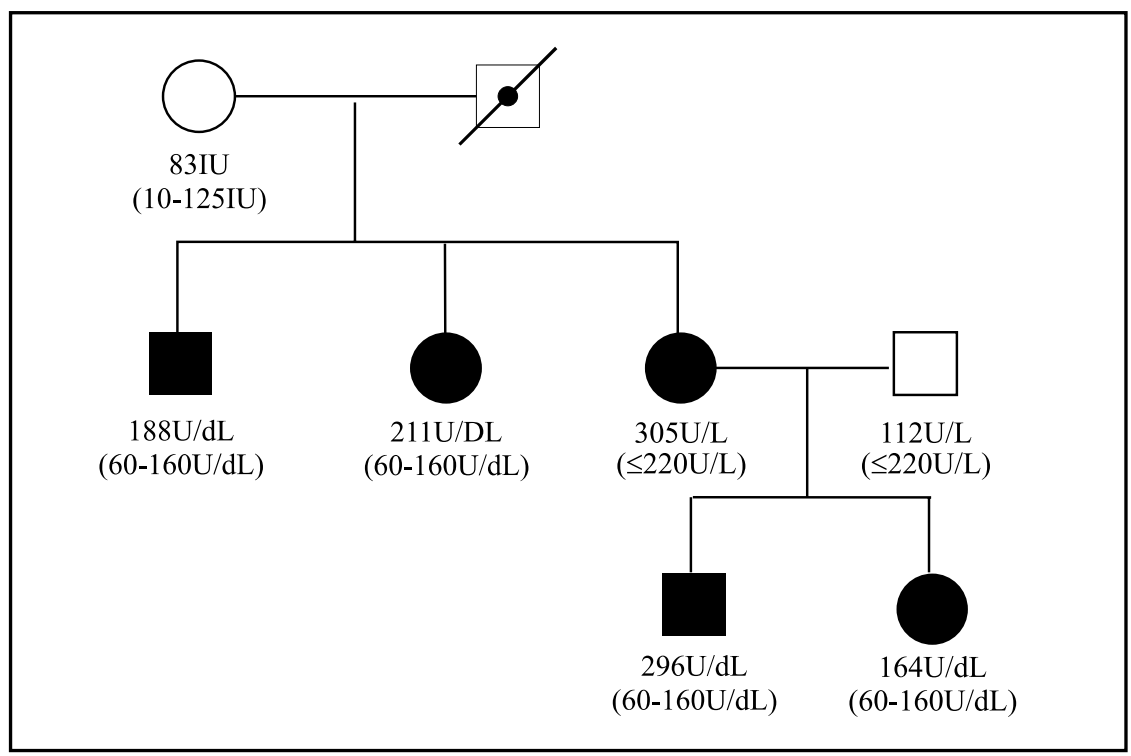

Figure 1 - Family Pedigree.

casions were all normal. Furthermore, there is no evidence that chronic nonpathological hyperamylasemia of pancreatic origin is an inherited condition.

Macroamylasemia is also an unlikely diagnosis for our patient because macroamylase was not detected in his serum.

Cuckow et al. ${ }^{1}$ described a condition that they called familial hyperamylasemia. It occurred in a of 6-yearold boy who was found to have persistently raised total serum amylase without evidence of any disease after extensive investigation for recurrent abdominal pain. Serum amylase concentrations were also found to be raised in the boy's other family members spanning 3 generations, and the pattern of inheritance was consistent with autosomal dominance.

The patient we described is very similar to the one reported by Cuckow et al. ${ }^{1}$. The total serum amylase concentration in our patient was persistently elevated. Raised total serum amylase was also found in 4 of our patient's family members. The maternal grandfather was deceased, so his blood sample could not be analyzed, and the maternal grandmother had a normal serum amylase. But since the patient's mother, as well as his uncle and aunt, were all affected, we could conclude that the maternal grandfather might have been affected. Thus, our patient also seems to have inherited this condition that spanned 3 generations, and the pattern of inheritance is also consistent with autosomal dominance.

The total serum amylase concentrations of the patient described by Cuckow et al. ${ }^{1}$, as well as those of the patient's family members, were only slightly elevated, though these authors called the condition familial hyperamylasemia. The boy had 4 total serum amylase determinations, and the results were: 168 Somogyi U/dL (normal range 40-160 U/dL); 336 Somogyi U/ dL (normal range $40-160 \mathrm{U} / \mathrm{dL}$ ); 226 Somogyi U/dL (normal range 40 - 160 $\mathrm{U} / \mathrm{dL}$ ), and $160 \mathrm{IU} / \mathrm{L}$ (normal range 1995 IU/L). The patient's father had a normal serum amylase of $68 \mathrm{IU} / \mathrm{L}$, and the brother' $s$ serum amylase was at the top of the normal range at $95 \mathrm{IU} / \mathrm{L}$ (normal range 19-95 IU/L). His mother, half sister, and maternal grandfather had raised concentrations at 144 IU/l, $138 \mathrm{IU} / \mathrm{L}$, and $112 \mathrm{IU} / \mathrm{L}$ respectively. Similarly, the total serum amylase concentrations from our patient as well as from his family members were also only slightly elevated.

Like the report of Cuckow et al. ${ }^{1}$, we also did not have a uniformity in the results of measurements of serum amylase because different kits and methods were used by the different laboratories. Since the patient was from another state of the country, the initial measurements of his serum amylase, as well as those of the family members, were performed in the laboratory from his original city. However, despite of the lack of uniformity of the kits, the elevated serum amylase concentrations were confirmed by our hospital's laboratory and also by two other private laboratories.

In familial hyperamylasemia, described by Cuckow et al. ${ }^{1}$, both pancreatic and salivary amylases are elevated. We could not determine the isoamylases, which could have enhanced the diagnostic accuracy by distinguishing the origin of the elevated serum amylase, either pancreatic type isoamylase, salivary type isoamylase, or both. However, we think that our patient presented many indications that are consistent with the diagnosis of familial hyperamylasemia. These indications include age group, slightly raised serum amylase levels, exclusion of diseases that lead to hyperamylasemia, normal serum lipase, no macroamylasemia, and autosomal dominant inheritance.

Since the first description of familial hyperamylasemia as a distinct entity in children made by Cuckow et al. ${ }^{1}$ in 1997, no more cases have been reported. As far as we know, this is the second description of this condition.

Familial hyperamylasemia must be considered in the differential diagnosis of hyperamylasemias in childhood. Knowledge of this disorder may avoid unnecessary diagnostic investigations and/or erroneous treatment of pancreatitis because of the presence of hyperamylasemia. 
KODA YKL e col. - Hiperamilasemia familiar. Rev. Hosp. Clín. Fac. Med. S. Paulo 57(2):77-82, 2002.

Paciente branco, masculino, sete anos, encaminhado com história de três episódios de dor abdominal no baixo ventre nos últimos dois anos e níveis elevados de amilase sérica. Ao exame físico encontrava-se em bom estado geral, com desenvolvimento pondoestatural normal e sem sinais ou sintomas de quaisquer anormalidades clínicas. Os exames complementares para investigação diagnóstica revelaram-se todos normais com exceção do exame parasitológico de fezes que revelou Ascaris lumbricoides e dos níveis séricos de amilase que se encontravam persistentemente elevados. Amilasemias realizadas nos familiares, todos assintomáticos, mostraram níveis normais no pai e na avó materna e elevados na mãe, na irmã , na tia e no tio maternos. Macroamilasemia foi excluída na criança e na mãe. $\mathrm{O}$ encontro de níveis séricos de amilase persistentemente elevados na criança e nos familares até três gerações e a exclusão de outras doenças que cursam com aumento da amilase sérica são consistentes com o diagnóstico de Hiperamilasemia Familiar. Até o presente momento, somente um caso semelhante foi descrito na literatura. Hiperamilasemia Familiar deve ser lembrada no diagnóstico diferencial das hiperamilasemias em crianças.

DESCRITORES: Hiperamilasemia. Amilase. Isoamilases. Macroamilase. Pancreatitis.

\section{REFERENCES}

1. CUCKOW PM, FOO AY, JAMAL A et al. - Familial hyperamylasemia. Gut 1997; 40: 689-690.

2. GULLO L - Chronic nonpathological hyperamylasemia of pancreatic origin. Gastroenterology 1996; 110: 1905-8.

3. HUMPHRIES LL, ADAMAS LJ, ECKFELDT JH et al. Hyperamylasemia in patients with eating disorders. Ann Intern Med 1987; 106(1): 50-2.

4. JAM I, SHOLAM M, WOLF RO et al. - Elevated serum amylase activity in the absence of clinical pancreatic or salivary gland disease; possible role of acute hypoxemia. Am J Gastroenterol 1978; 70(5): 480-8.
5. TSIANOS EB, JALALI MT, GOWENLOCK AH et al. - Ethnic "hyperamylasemia": clarification by isoamylase analysis. Clin Chim Acta 1982; 124: 13-21.

6. D'AVANZO M, COBBAERT C, TOLONE C et al. - Macroamylasemia in a 5-year-old girl. J Pediatr Gastroenterol Nutr 1992; 14: 1046.

7. CATASSI C, GUERRIERI A, NATALINI G, BUSCO F et al. Macroamylasaemia and selective IgA deficiency. Arch Dis Child 1986; 61(7): 704-6.

8. KAMEYA S, HAYAKAWA T, KAMEYA A et al. - Clinical value of routine isoamylase analysis of hyperamylasemia. Am J Gastroenterol 1986; 81(5): 358-64. 
9. PIEPER-BIGELOW C, STROCCHI A \& LEVITT MD - Where does serum amylase come from and where does it go? Gastroenterol Clin North Am 1990; 19(4): 793-810.

10. CLINK D, WEAVER D, BOUWMAN D et al. - Clinical application of organ specific isoamylases. Am Surg 1982; 48(8): 422-5.

11. OTSUKI M - Usefulness of amylase isoenzyme determination for the diagnosis of pancreatic diseases. Nippon Rinsho 1995; 53(5): 118491.

12. WEAVER DW, BOUWMAN DL, WALT AJ et al. - A correlation between clinical pancreatitis and isoenzyme patterns of amylase. Surgery 1982; 92(4): 576-80.
13. WARSHAW AL \& HAWBOLDT MM - Puzzling persistent hyperamylasemia, probably neither pancreatic nor pathologic. Am J Surg 1988; 155(3): 453-6.

14. KAMEYA S, HAYAKAWA T, KAMEYA A et al. - Hyperamylasemia in patients at an intensive care unit. J Clin Gastroenterol 1986; 8(4): $438-42$.

15. GOLDBERG DM \& SPOONER RJ - Amylase, isoamylase and macroamylase. Digestion 1975, 13(1-2): 56-75.

Received for publication on October 05, 2001. 